\title{
Perilymphatic Fistula
}

\section{A Controversial Issue}

Guest Editor

Jean-Philippe Guyot, Geneva, Switzerland

9 figures, 8 tables, 1999

KARGER Basel· Freiburg $\cdot$ Paris $\cdot$ London $\cdot$ New York $\cdot$

New Delhi $\cdot$ Bangkok $\cdot$ Singapore $\cdot$ Tokyo $\cdot$ Sydney 


\section{KARGER}

S. Karger

Medical and Scientific Publishers Basel $\cdot$ Freiburg $\cdot$ Paris $\cdot$ London New York $\cdot$ New Delhi $\cdot$ Bangkok

Singapore $\cdot$ Tokyo $\cdot$ Sydney
Drug Dosage

The authors and the publisher have exerted every effort to ensure that drug selection and dosage set forth in this text are accord with current recommendations and practice at the tim of publication. However, in view of ongoing research, changes in government regulations, and the constant flow of informaion relating to drug thera

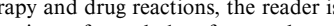
rged to check the package insert for each drug for any change in indications and dosage and for added warnings and precautions. This is particularly important when the recommended agent is a new and/or infrequently employed drug.
All rights reserved.

No part of this publication may be translated into other languages, reproduced or utilized in any form or by any means, electronic or mechanical, including photocopying, recording microcopying, or by any information storage and retrieval system, without permission in writing from the publisher or, in petocopying, direct payment of a specified fee the Copyright Clearance Center (see 'General Information').

(c) Copyright 1999 by S. Karger AG,

P.O. Box, CH-4009 Basel (Switzerland)

Printed in Switzerland on acid-free paper by

Reinhardt Druck, Basel 


\section{Editorial}

169 The Positive Aspect of Unresolved Questions:

The Example of Perilymphatic Fistula

Guyot, J.-P. (Geneva)

171 Experimental Perilymphatic Fistulas Böhmer, A. † (Zurich)

177 Perilymphatic Fistula: Pathophysiology, Diagnosis and Management Gacek, R.R. (Syracuse, N.Y.)

182 Perilymphatic Fistula: A Washington, D.C., Experience Fitzgerald, D.C.; Getson, P.; Brasseux, C.O. (Washington, D.C.)

190 Perilymph Fistula: Myth or Reality? Legent, F.; Bordure, P. (Nantes)

197 Perilymphatic Fistulae. When, Why and How to Operate Kohut, R.I.; Ryu, J.H. (Winston-Salem, N.C.); Hinojosa, R. (Chicago, Ill.); Burke, A.J.C (Winston-Salem, N.C.)

207 Perilymphatic Fistula Associating with Cochleovestibular and Autonomic Nervous System Disorders Miniconi, P. (Carpentras)

211 Congress Calendar $\cdot$ Calendrier des congrès $\cdot$ Kongresskalender 